Other roundtables and panels drawing over 100 participants were sessions on "International Political Economy Meets International Security" chaired by Benjamin J. Cohen of the University of California, Santa Barbara; "Don't Fire that Canon: The Classics and Political Education" chaired by Terence Ball of the University of Minnesota; "Roundtable on Bureaucracy and Organization Theory" chaired by Marcia Lynn Whicker, Virginia Commonwealth University; "Roundtable on Could the Democrats Lose Congress" chaired by Jerrold Schneider, University of Delaware; and "Roundtable on the Political Philosophy of Michael Walzer" chaired by Joseph Carens, University of Toronto.

Panels involving presentation of papers which drew larger crowds included "Institutions and Conflict: New Perspectives on Key Transformations of American Politics" chaired by Richard M. Vallelly, MIT; "The Internationalization of Social Movements" chaired by Aristide Zolberg, New School for Social Research, and Sidney Tarrow, Cornell University; and "Regional Conflict Resolution and Mediation"' chaired by Mary-Jane Deeb, American University.

On Thursday evening Theodore J. Lowi, Cornell University, gave his Presidential Address, "The State in Political Science: How We Become What We Study," following the presentation of Association awards. As is customary, his address will be printed in the March issue of the Review. The program included a Plenary Session on "America as a Model for the World" presented by Kenneth Waltz, Theodore Gurr, and Frances Fukuyama and the John Gaus Lecture offered by Norton Long. The plenary and Gaus lecture appear in this issue of $P S$. Finally, The Honorable Richard Cheney, Secretary of Defense, presented the first annual Pi Sigma Alpha lecture in conjunction with the meeting.

\section{Short Courses Offered at Annual Meeting}

One hundred and twenty graduate student and professional members of the APSA met before the Annual Meeting this summer to attend APSA short courses. The Association offered courses in data resources, featuring the National Archives, the National Security Archives, the Vanderbilt New Archives, and the Purdue Public Affairs Video Archives; in the design and use of Poli-Ware computer simulations; in teaching issues of American cultural pluralism and law; and in the "organization of scholarly work" for graduate students.

The graduate student course inaugurated an annual series for graduate students offered by leading scholars in political science on issues in professional life. This year Aaron Wildavsky, University of California, Berkeley, spoke to 63 graduate students.

Next year the organized sections are expected to play an active role in organizing short courses addressing issues in their fields of interest to a broad spectrum of political scientists. This year, in addition to APSA sponsorship, the IBM Corporation helped to sponsor the Poli-Ware course, and the American Bar Association supported the teaching issues course.

\section{Association Distributes Annual Awards}

Dissertations submitted by the University of Minnesota won two of the eight dissertation awards presented at the Awards Ceremony at the annual meeting August 29. They were dissertations written by Michael Barnett, now at the University of Wisconsin, Madison, which won the Gabriel Almond Award in the field of comparative politics and by Christopher McGrory Klyza, now at Middlebury College, which won the Harold D. Lasswell Award in the field of policy studies. Raymond Duvall and Virginia Gray were the dissertation chairs.

Harvard University also had two dissertation winners: Debora L. Spar, Harvard University, won the Helen Dwight Reid Award in the field of international relations, law and politics, and Mark Lilla, New York University, won the Leo Strauss Award in the field of political philosophy.

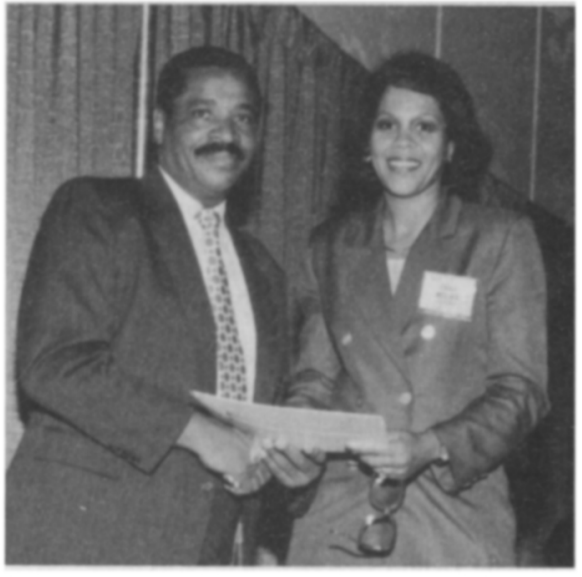

Paula McClain presents C. Payne Lucas of Africare with Humphrey Award.

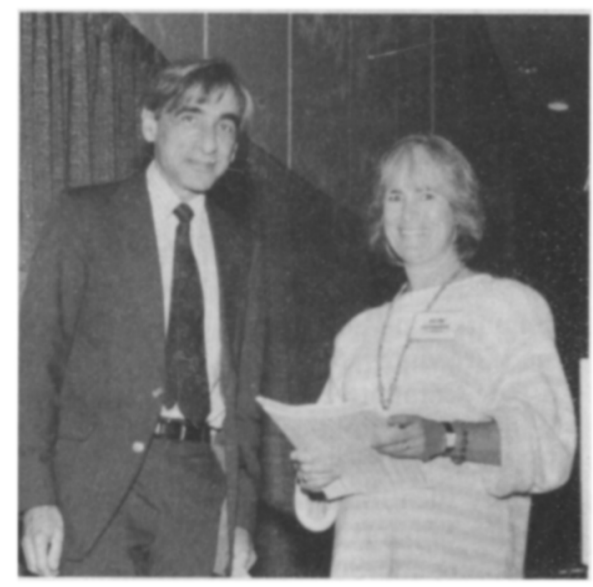

Michael Walzer receives Lippincott Award from Arlene Saxonhouse.

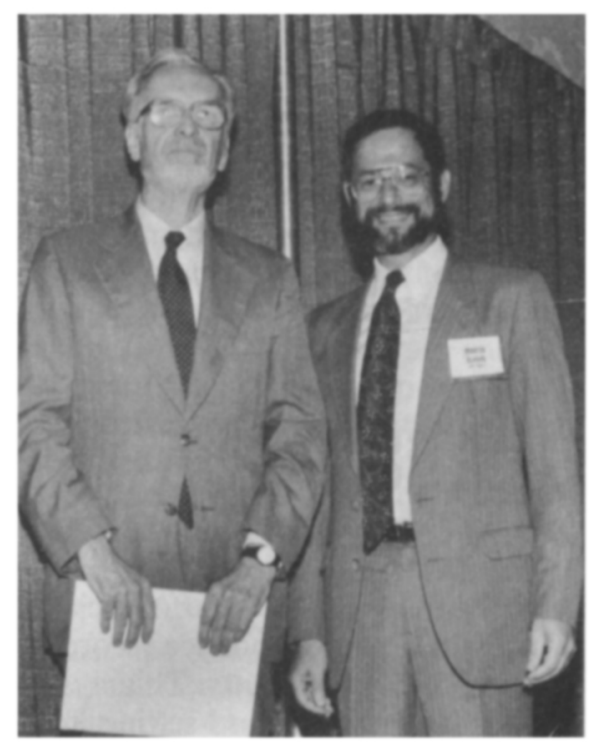

Charles E. Lindblom receives Wilson Award from Martin Schain. 


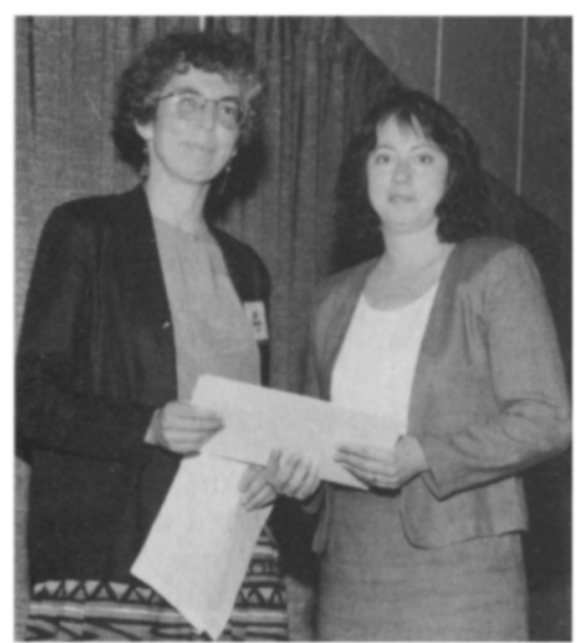

Doris Marie Provine presents Corwin Award to Terri Jennings Peretti.

Dissertation chairs were Stanley

Hoffman and Judith N. Shklar.

Other dissertation winners were

Michael B. Berkman, Pennsylvania

State University, the William Ander-

son Award in the field of inter-

governmental relations, submitted by

Indiana University; Terri Jennings

Peretti, Santa Clara University, the

Edward S. Corwin Award in the

field of public law, submitted by the

University of California, Berkeley;

Christopher Peter Gilbert, Washing-

ton University, the E. E. Schatt-

schneider Award in the field of

American government, submitted by

Washington University; and Alan

Abramson, Urban Institute, the

Leonard D. White Award in the field of public administration, submitted by Yale University.

Kenneth N. Waltz, University of California, Berkeley, won the Heinz Eulau Award for the best article published in The American Political Science Review during 1990. Bartholomew H. Sparrow, University of Texas at Austin, won the Franklin L. Burdette Pi Sigma Alpha Award for the best paper presented at the 1990 annual meeting.

Book award winners included Michael Walzer, Institute for Advanced Study, who won the Benjamin E. Lippincott Award for a work of exceptional quality by a living political theorist that is still considered significant after a time span of at least 15 years since the original publication for his The Revolution of the Saints: A Study in the Origins of Radical Politics, published by Harvard University Press in 1965. Charles E. Lindblom, Yale University, won the Woodrow Wilson Foundation Award for the best book published in the U.S. during 1990 on government, politics or international affairs for his Inquiry and Change, published by Yale University Press and the Russell Sage Foundation. The Ralph J. Bunche Award for the best work exploring the phenomenon of ethnic and cultural pluralism was won by Frank R. Parker, Lawyers' Committee for Civil Rights Under Law, for his Black Votes Count, published by the University of North Carolina Press. The Gladys M. Kammerer Award for the best publication in the field of U.S. national policy was won by James A. Morone, Brown University, for his The Democratic Wish, published by Basic Books. The Victoria Schuck Award for the best book on women and politics was won by Iris M. Young, University of Pittsburgh for her Justice and the Politics of Difference, published by Princeton University Press, and by Jane Sherron de Hart and Donald G. Mathews, University of North Carolina, for their Sex, Gender and the Politics of ERA, published by Oxford University Press.

Norton E. Long, Professor Emeritus, University of Missouri, St. Louis, was this year's John Gaus Distinguished Lecturer, honoring the recipient's lifetime of exemplary scholarship in the joint tradition of political science and public administration and, more generally, to recognize achievement and encourage scholarshp in public administration.

Other career awards were the Hubert H. Humphrey Award for notable public service by a political scientist, presented to Zbigniew Brzezinski, Center for Strategic and International Studies, and C. Payne Lucas, Africare and the Carey McWilliams Award, to honor a major journalistic contribution to our understanding of politics, presented to Molly Ivins, Dallas Times-Herald.

Editor's Note: For additional details on each award and the full text of citations, see the Gazette in this issue of $P S$.

\section{APSA Organized Sections Distribute Awards at Annual Meeting}

Thirteen of the twenty-six APSA Organized Sections used the 1991 Annual Meeting as an opportunity to recognize distinctive scholarship and career service within their fields of political science.

\section{Federalism and Intergovernmental Relations Organized Section}

Vincent Ostrom, of the Workshop in Political Theory and Policy, Indiana University, was the recipient of the Special Achievement Award for significant contributions to the study of federalism. The award was presented by Daniel J. Elazar of Temple University and Bar-Ilan University.

\section{Law, Courts, and Judicial Process Organized Section}

Susan E. Lawrence, Rutgers University, was awarded the C. Herman Pritchett Prize for the outstanding book published in 1990 for The Poor in Court: The Legal Services Program and Supreme Court Decision Making, published by Princeton University Press. The prize, established last year, was awarded by Professor

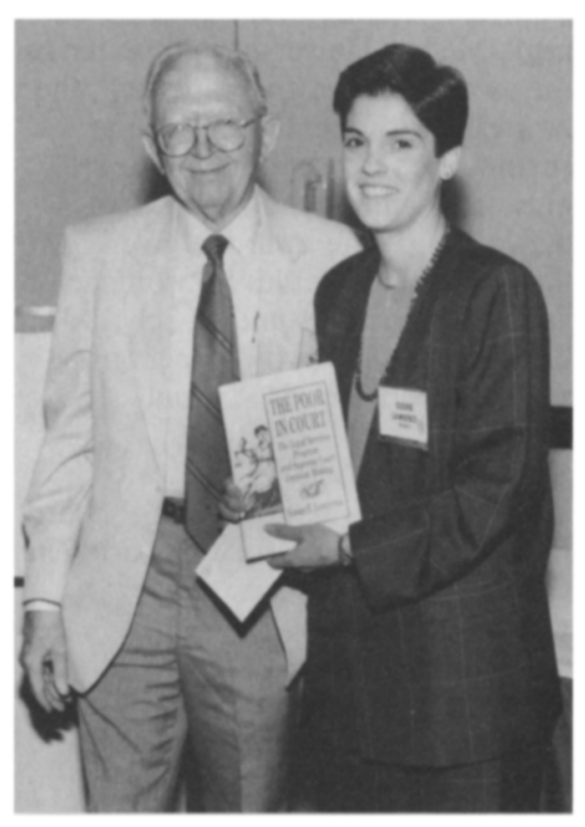

Susan E. Lawrence, winner of the first C. Herman Pritchett Award, with C. Herman Pritchett of the Law, Courts, and Judicial Process Section. 